\title{
PENAMBAHAN TEPUNG SERANGGA PADA MEDIA PERBANYAKAN UNTUK MENINGKATKAN VIRULENSI Beauveria bassiana TERHADAP WALANG SANGIT
}

\author{
Disusun oleh : \\ Widya Sari**) \\ Muhammad Latiful Khobir*)
}

\begin{abstract}
Abstrak
Padi Pandanwangi merupakan padi lokal khas Cianjur yang hanya dapat tumbuh optimal di beberapa Kecamatan di Kabupaten Cianjur. Walang Sangit (Leptocorisa oratorius )merupakan hama yang paling sering menimbulkan kerusakan berat pada tanaman padi terutama pada saat fase generatif. Pemanfaatan cendawan entomopatogen berpotensi untuk mengendalikan hama walangsangi. Salah satu jenis cendawan entomopatogen yang cukup efektif adalah B.bassiana. Penelitian ini dilaksanakan pada bulan April - Mei 2019, menggunakan Rancangan Acak Lengkap yang terdiri dari 3 perlakuan dan 5 ulangan, yaitu 1 (Tepung beras 100 gram+tepung jangkrik 15\%), 2 (Tepung beras 100 gram+tepung kroto 15\%), dan 3 sebagai kontrol (Tepung beras 100 gram). Hasil pengamatan menunjukkan bahwa mortalitas Walang Sangit terbaik yaitu pada perlakuan 1 (Tepung beras 100 gram+tepung jangkrik 15\%) dengan rata-rata-mortalitas pada 48 jam adalah 60\%, pada 72 jam adalah 33\%, Hasil analisis $\mathrm{LT}_{50}$ menunjukkan bahwa perlakuan 1 dengan jumlah konidia

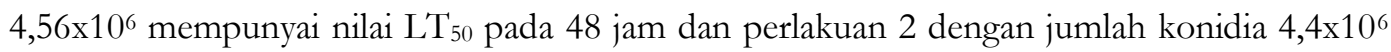
menunjukkan $\mathrm{LT}_{50}$ pada $72 \mathrm{jam}$, sedangkan perlakuan 3 dengan jumlah konidia 4,24x106 menunjukkan $\mathrm{LT}_{50}$ pada 144 jam. Penambahan tepung serangga pada media biakan dapat merangsang cendawan entomopatogen menghasilkan enzim khitinase yang mampu mendegradasi khitin pada kutikula walang sangit.
\end{abstract}

Kata kunci: Padi Pandanwangi, B.bassiana Tepung Jangkrik, Tepung Kroto Mortalitas LT $_{50}$

\begin{abstract}
Pandanwangi Rice is a local rice typical of Cianjur that can only grow optimally in several subdistricts in Cianjur Regency. Stink Bugs (Leptocorisa oratorius) is a pest that most often causes beavy damage to rice plants especially during the generative phase. The use of entomopathogenic fungi has the potential to control the pests. One type of entomopathogenic fungus which is quite effective is B. assiana. This research was conducted in April - May 2019, using a Completely Randomized Design consisting of 3 treatments and 5 replications, namely 1 (100 gram rice flour $+15 \%$ cricket flour), 2 (100 gram rice flour + $15 \%$ cacao flour), and 3 as controls (100 gram rice flour). The results showed that the best Stink. Bugs mortality was in treatment 1 (100 gram + cricket flour 15\%) with an average mortality of 48 bours was $60 \%$, at 72 hours was 33\% The analysis results of $L_{50}$ show that treatment 1 with the number of conidia

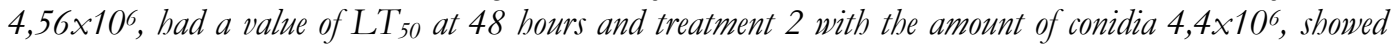
$L T_{50}$ at 72 hours, while treatment 3 with the number of conidia 4,24x106, showed $L_{50}$ at 144 hours. The
\end{abstract}


addition of insect flour to the culture medium could stimulate the entomopathogenic fungus to produce the enzyme khitinase which was able to degrade chitin in the cuticle of Stink Bugs.

Key word: Pandanwangi Rice, Beauveria bassiana. Cricket Flour, Kroto Flour, Mortality, $L T_{50}$.

*) Alumni Fakultas Sains Terapan UNSUR

**) Dosen Fakultas Sains Terapan UNSUR 


\section{PENDAHULUAN}

Tanaman padi merupakan tanaman pangan utama di Indonesia karena lebih dari setengah penduduk Indonesia menjadikan beras sebagai sumber makanan pokok. Padi pandanwangi adalah salah satu jenis varietas padi bulu (javanica) yang tumbuh dan berkembang di Cianjur yang juga merupakan salah satu varietas lokal khas Cianjur. Beras Pandanwangi Cianjur (Aromatic rice) merupakan salah satu jenis beras kualitas premium dan komoditas unggulan Kabupaten Cianjur. Padi Pandanwangi mulai berkembang di Kabupaten Cianjur pada tahun 1970. Penyebaran padi Pandanwangi di Cianjur mulai berkembang dari Kecamatan Warungkondang ke 6 Kecamatan lain di Wilayah Kabupaten Cianjur, seperti Kecamatan Cugenang, Kecamatan Cianjur, Kecamatan Cilaku, Kecamatan Cibeber, Kecamatan Cempaka dan Kecamatan Gekbrong (MP3C, 2015). Sekarang daerah tersebut menjadi daerah sentra pelestarian dan pengembangan produksi padi Pandanwangi.

Terdapat beberapa jenis hama tanaman padi Pandanwangi, seperti hama wereng hijau yang menyebabkan penyakit tungro, walang sangit, kepinding tanah dan wereng coklat. Wereng coklat sudah menyerang tanaman padi di Indonesia sejak pertengahan tahun 1970-an, selain dari pada wereng coklat (Sembiring, 2013).

Walang sangit (Leptocorisa oratorius) adalah serangga yang menjadi hama penting di tanaman budidaya terutama padi. Serangga ini mudah dikenali dari bentuknya yang memanjang, berukuran sekitar $2 \mathrm{~cm}$, berwarna merah dan hitam. Walang sangit adalah anggota ordo Hemiptera. Walang sangit mengisap cairan tanaman dari tangkai bunga (paniculae) sehingga menyebabkan tanaman kekurangan hara dan menguning (klorosis), dan perlahan melemah. Hama ini bukan saja dapat menurunkan hasil tetapi juga menurunkan kualitas gabah seperti bintik-bintik coklat di gabah akibat isapan cairan dari hama tersebut. Kerusakan tanaman padi oleh hama walang sangit seranganya dapat nenurunkan hasil $10-40 \%$ tetapi di serangan yang berat akibat populasi yang tinggi dapat menurunkan hasil sampai 100\% atau puso (BBPTP, 2015).

Penggunaan insektisida sintetik sebagai pengendali hama telah menimbulkan beberapa masalah seperti munculnya ketahanan hama terhadap insektisida, resurjensi hama, letusan hama kedua, dan berkurangnya musuh alami hama (Untung, 2001). Berdasarkan hal tersebut perlu dicari alternatif untuk pengendalian hama, seperti penggunaan jamur entomopatogen sebagai agens hayati pengendali hama. Ada beberapa alasan mengapa jamur entomopatogen menjadi pilihan untuk pengandalian hama. Alasan tersebut diantaranya adalah jamur entomopatogen mempunyai kapasitas reproduksi yang tinggi, siklus hidup yang pendek, dapat membentuk spora yang dapat bertahan lama di alam, bahkan dalam kondisi yang tidak menguntungkan sekalipun (Soetopo dan Indriyani, 2007). Penggunaan jamur entomopatogen juga relatif aman, bersifat selektif, kompatibel dengan berbagai komponen pengendalian dalam PHT, relatif mudah diproduksi, dan kemungkinan menimbulkan resistensi sangat kecil (Soetopo dan Indriyani, 2007). Salah satu jamur entomopatogen yang sudah teruji memiliki potensi untuk pengendalian hama yaitu Beauveria bassiana (Suharto et al., 1998).

Cendawan B.bassiana mudah diperbanyak secara in vitro, namun ternyata dalam proses perbanyakan secara in vitro dapat terjadi penurunan kualitas dan virulensinya Penurunan kualitas spora jamur entomopatogen dapat disebabkan karena berkurangnya sumber khitin, dan protein di media perbanyakan, oleh karena itu sangat diperlukan teknik perbanyakan dan cara aplikasi yang bisa mempertahankan kualitas, dan patogenisitas cendawan (Herlinda et al., 2006). Hasil penelitian Nuryanti et al., 
(2013) menunjukkan bahwa cendawan B.bassiana yang ditumbuhkan di media beras dengan penambahan tepung belalang atau tepung dedak, mampu menyebabkan mortalitas walang sangit sebesar $78 \%$ dan $71 \%$.

Penelitian tentang penambahan beberapa macam tepung serangga selain tepung belalang dan tepung kulit udang ke dalam media perbanyakan cendawan B.bassiana belum pernah dilaporkan sebelumnya, sehingga berdasarkan hal tersebut perlu dilakukan penelitian penambahan beberapa jenis tepung serangga di media perbanyakan. Penelitian ini diharapkan dapat menemukan jenis tepung serangga yang dapat meningkatkan virulensi cendawan $B$. bassiana terhadap hama sasaran.

Penelitian tentang penambahan beberapa macam tepung serangga ke dalam media perbanyakan cendawan $B$. bassiana. guna meningkatkan virulensinya belum pernah dilaporkan sebelumnya, sehingga berdasarkan hal tersebut perlu dilakukan penelitian penambahan beberapa jenis tepung serangga pada media perbanyakan. Penelitian ini diharapkan dapat menemukan jenis tepung serangga yang dapat meningkatkan virulensi cendawan B. bassiana

Tujuan penelitian ini adalah untuk mengetahui pengaruh penambahan tepung serangga pada media tepung beras untuk perbanyakan cendawan $B$. bassiana terhadap mortalitas dan waktu kematian $50 \%\left(\mathrm{LT}_{50}\right)$ hama walang sangit.

\section{METODE PENELITIAN}

\section{Waktu dan Tempat}

Penelitian ini dilakukan di Pusat Studi dan Pengembangan Plasma Nutfah Pandanwangi, BALITHI (Balai Penelitian Tanaman Hias) Segunung, dan Fakultas Sains Terapan Universitas Suryakancana Cianjur, yang beralamatkan di Kp. Sedong, Kecamatan Cianjur, Kabupaten Cianjur pada bulan Maret-April 2019.

\section{Persiapan Isolat $\boldsymbol{B}$. bassiana}

Biakan murni B. bassiana diperoleh dari Satuan Pelayanan Balai Perlindungan Tanaman Pangan dan Hortikultura Wilayah I Cianjur. Sebelum digunakan terlebih dahulu dilakukan isolasi dan perbanyakan terhadap cendawan B. bassiana pada media PDA di laboratorium. Setelah diperoleh biakan $B$. Bassiana, selanjutnya ditumbuhkan pada media tepung beras.

Proses pembuatan starter yaitu : tepung beras ditimbang, dimasukkan ke dalam kantong plastik tahan panas masing-masing 100 gram. Selanjutnya beras dalam kantung plastik tersebut disterilkan pada autoclave dengan temperatur $121{ }^{\circ} \mathrm{C}$, tekanan 15 psi dan dikonstankan selama \pm 2 jam, lalu diangkat dan didinginkan. Pada media tepung beras yang steril tersebut dilakukan inokulasi isolat murni B. Bassiana dengan menggunakan jarum ose steril. Selanjutnya plastik dikocok agar spora cendawan dapat tersebar merata pada media beras, kemudian diinkubasikan pada suhu kamar selama \pm 2 minggu. Perbanyakan massal B. Bassiana dilakukan dengan proses yang sama seperti pembuatan starter, hanya tidak menggunakan inokulasi isolat murni melainkan menggunakan starter inokulum dengan perbandingan satu bagian starter untuk 5 bagian media perbanyakan. Media perbanyakan yang digunakan ada 3 macam yaitu: (P1 media perbanyakan tepung beras ditambah 15\% tepung jangkrik, (P2) media perbanyakan tepung beras ditambah 15\% tepung kroto, (P3) media perbanyakan tepung beras saja.

\section{Persiapan Serangga Uji}

Walang sangit sebagai serangga uji diperoleh dari lahan sawah, kemudian dipelihara dan dibiakkan dalam kandang perkembang biakan yang terbuat dari kayu dengan ukuran tinggi $100 \mathrm{~cm}$ dan lebar $100 \mathrm{~cm}$ yang telah berisi tanaman padi dalam pot. 


\section{Persiapan Tanaman Padi}

Mempersiapkan bibit padi di bagi menjadi dua yaitu untuk pakan perbanyakan walang sangit dimana benih padi di semai dalam nampan yang telah terisi sekam bakar sebagai media dan perbanyakan bibit untuk proses aplikasi dimana benih padi di semai dalam gelas plastik sampai padi fase generatif.

\section{Penghitungan Jumlah Konidia}

Untuk mengetahui jumlah teknik perbanyakan dengan penambahan beberapa bahan terhadap konidia cendawan Beauveria bassiana, maka dilakukan pengitungan jumlah konidia. Penghitungan jumlah konidia dilakukan dengan beberapa langkah. Langkah pertama adalah jamur entomopatogen dari masing-masing teknik perbanyakan ditimbang sebanyak 1 gram. Lalu cendawan yang telah ditimbang tersebut dicampur aquades sebanyak $10 \mathrm{ml}$ kemudian dihancurkan/dilumatkan, lalu disaring sehingga didapat suspensi konidia cendawan. Langkah selanjutnya yaitu, ruang hitung Haemacytometer ditutup dengan kaca obyek dan diteteskan suspensi sebanyak $1 \mathrm{cc}$ dengan pipet tetes, sehingga suspensi mengalir ke bawah kaca obyek dan ruang hitungpun dapat terisi. Terakhir jumlah konidia dihitung dalam lima kotak besar yang masing-masing dilakukan di bawah mikroskop, penghitungan diulang 2 kali. Jumlah konidia dicatat dan dihitung dengan rumus:

Keterangan:

$$
v=\frac{j}{n x t}
$$

$\mathrm{v}=$ volume

$\mathrm{j}=$ jumlah konidia

$\mathrm{n}=$ jumlah kotak besar

$\mathrm{t}=$ jumlah kotak pengecil

\section{Pembuatan Larutan Insektisida Hayati}

Larutan insektisida hayati dibuat dengan cara mengambil 10 gram media biakan yang telah ditumbuhi Beawveria bassiana, dilumatkan lalu campurkan ke dalam $200 \mathrm{ml}$ aquades, kemudian diaduk hingga rata dengan menggunakan rotamixer. Selanjutnya campuran tersebut disaring untuk diaplikasikan dalam pengujian.

\section{Aplikasi}

Insektisida hayati sebanyak 10 gram cendawan B.bassiana dengan kerapatan konidia disetiap perlakuan yaitu:

a. Tepung beras + tepung jangkrik : 4,56 $\mathrm{x} 10^{6}$,

b. Tepung beras + tepung kroto : 4,4 $\mathrm{x}$ $10^{6}$,

c. Tepung beras : 4,24 x $10^{6}$

Dilakukan dalam air dan diaduk rata untuk memperoleh nilai Mortalitas, dan mengetahui tingkat virulensi jamur B.bassiana dalam media tepung yang dihitung pada 12 jam selama 8 hari. Teknik aplikasi yang digunakan yaitu metode kontak (pada metode ini serangga uji disemprot berbagai konsentrasi insektisida hayati).

\section{Rancangan Percobaan}

Penelitian ini adalah penelitian eksperimental dengan menggunakan Rancangan Acak Lengkap (RAL) yang terdiri dari 3 perlakuan yaitu:

1. Tepung beras 100 gram+tepung jangkrik 15\% (BJ)

2. Tepung beras 100 gram+tepung kroto $15 \%$ (BK)

3. Tepung beras 100 gram (B)

Semua biakan massal tersebut sudah ditumbuhi oleh jamur Beamveria bassiana dan sudah berumur 14 hari. Setiap perlakuan diberikan 5 kali ulangan. Penelitian ini menggunakan metode kontak (serangga uji disemprot berbagai konsentrasi insektisida hayati). Setiap percobaan menggunakan serangga uji walang sangit berjumlah 3 ekor.

Adapun tahap uji penambahan tepung serangga pada media perbanyakan terhadap virulensi B.bassiana. yaitu sebagai berikut: 
1. Menyiapkan botol pelastik kemudian menempelkan kertas label yang telah diberikan kode setiap perlakuan dan ulangan kebagian tengah aqua selanjutnya memasukkan malai padi Pandanwangi. Penggunaan botol dimaksudkan untuk mempermudah pengontrolan setelah pengaplikasian.

2. Membuat larutan insektisida hayati dalam gelas ukur dengan cara mengambil 10 gram media biakan yang telah ditumbuhi Beauveria bassina. dilumatkan lalu campurkan ke dalam $200 \mathrm{ml}$ aquades, kemudian diaduk hingga rata dengan menggunakan rotamixer. Selanjutnya campuran tersebut disaring untuk diaplikasikan dalam pengujian.

3. Mengumpulkan serangga uji dari tempat pemeliharaan dengan menggunakan tangan.

4. Memasukkan serangga uji ke dalam botol plastik yang berisikan malai padi yang matang susu padi Pandanwangi dengan 3 serangga uji perbotol dan setiap botol dilubangi bagian tengahnya menggunakan kawat panas untuk memastikan serangga uji mendapatkan udara untuk bernapas dan setiap lubang berukuran kecil yang berjumlah lebih dari 5 lubang perbotolnya.

5. Melakukan pengamatan terhadap perilaku belalang setelah aplikasi uji biopestisida

6. Mencatat jumlah serangga uji yang mati pada setiap perlakuan pencatatan dilakukan pada 12 jam selama 8 hari.

\section{Teknik Pengumpulan Data}

Pengamatan dilakukan setiap 12 jam selama 8 hari setelah aplikasi. Pengamatan meliputi mortalitas serangga uji, waktu kematian (periode letal).
1. Mortalitas

$$
\begin{aligned}
& \text { Persentase mortalitas } \\
& \text { serangga uji dihitung dengan } \\
& \text { menggunakan rumus (Susilo et al., } \\
& \text { 1993), yaitu: } \\
& \text { P = A/B x } 100 \%, \\
& \text { Keterangan: } \\
& \mathrm{P}=\text { persentase kematian serangga uji } \\
& \text { A = jumlah serangga uji mati selama } 8 \\
& \text { hari pengamatan } \\
& \text { B = jumlah serangga uji awal per unit } \\
& \text { percobaan. }
\end{aligned}
$$

2. Waktu kematian 50\% (Lethal Time) $\left(\mathrm{LT}_{50}\right)$

Penentuan $\mathrm{LT}_{50}$ dilakukan untuk mengetahui berapa waktu yang dibutuhkan untuk mengakibatkan kematian hama sebanyak 50\% dengan menggunakan probit analisys.

\section{Teknik Analisis Data}

Data yang diperoleh diolah menggunakan bantuan software microsoft excel dan Minitab. Data yang diperoleh dari pengamatan dengan sidik ragam (ANOVA) jika terdapat pengaruh dilakukan uji lanjut TUKEY dengan taraf kepercayaan $95 \%$ atau a $5 \%$ pada program Minitab dan uji lanjut regresi pada program software microsoft excel. Nilai $\mathrm{LT}_{50}$ di analisis dengan menggunakan probit analisis pada program software microsoft excel.

\section{HASIL DAN PEMBAHASAN}

Mortalitas Walang Sangit (Leptocorisa oratorius) Pada penelitian yang dilakukan diperoleh data kematian walang sangit berupa kematian walang sangit pada rentang waktu 48 jam, 72 jam, dan 144 jam. Dengan menggunakan tiga perlakuan berbagai konsentrasi. dapat dilihat pada tabel 1. 
Tabel 1. Rata-rata Mortalitas (\%) Walang Sangit.

\begin{tabular}{ccccc}
\hline & & \% Mortalitas pada waktu pengamatan (jam) \\
\hline & Perlakuan (jumlah konidia) & $\mathbf{4 8}$ & $\mathbf{7 2}$ & $\mathbf{1 4 4}$ \\
\hline I & TB 100 gram + TJ 15\% $\left(4,56 \times 10^{6}\right)$ & $60 \mathrm{a}$ & $33 \mathrm{a}$ & $07 \mathrm{~b}$ \\
II & TB 100 gram + TK 15\% $\left(4,4 \times 10^{\circ}\right)$ & $47 \mathrm{a}$ & $47 \mathrm{ab}$ & $07 \mathrm{~b}$ \\
III & TB 100 gram $\left(4,24 \times 10^{\circ}\right)$ & $20 \mathrm{a}$ & $07 \mathrm{~b}$ & $46 \mathrm{a}$ \\
\hline
\end{tabular}

Angka pada kolom yang sama diikuti oleh huruf yang sama tidak berbeda nyata menurut uji TUKEY pada taraf alfa $5 \%$.

Ket: Tepung Beras (TB), Tepung Jangkrik (TJ), Tepung Kroto (TK).

Tabel 1 menunjukkan aplikasi beberapa konsentrasi larutan insektisida hayati cendawan B.bassiana. Memberikan pengaruh terhadap mortalitas Walang sangit hasil pengamatan pada 48 jam setelah aplikasi, bioinsektisida denga perlakuan. 1 (Tepung beras 100 gram + tepung jangkrik 15\%) menujukkan kematian serangga uji $60 \%$ (9), perlakuan ke 2 (Tepung beras 100 gram+tepung kroto 15\%) kematian serangga uji 46,6\% (7) dan perlakuan ke 3 (Tepung beras 100 gram) kematian serangga uji 20\% (3) tidak terlihat memberikan dampak yang lebih banyak terhadap mortalitas walang sangit. Hasil penelitian Herlinda et al., (2006) menunjukkan penambahan bahan yang mengandung khitin dan protein seperti tepung jangkrik pada media biakan dapat merangsang cendawan entomopatogen menghasilkan enzim khitinase. Samsinakova et al., (1971) melaporkan cendawan entomopatogen menghasilkan enzim khitinase yang mampu mendegradasi khitin pada kutikula serangga. Dengan demikian, peningkatan kemampuan B.bassiana membunuh walang sangit disebabkan adanya peningkatan enzim khitinase yang mendegradasi kutikula dan kitin serangga uji pada proses infeksi walang sangit.

Pengamatan pada 72 jam setelah aplikasi beberapa konsentrasi larutan insektisida hayati cendawan B.bassiana. didapatkan perlakuan terbaik yaitu pada perlakuan pertama (Tepung beras 100 gram+tepung jangkrik 15\%) dengan kematian serangga uji 33,3\% (5), perlakuan ke 2 (Tepung beras 100 gram+tepung kroto $15 \%$ ) dengan kematian serangga uji 46,6\% (7) dan perlakuan ke 3 (Tepung beras 100 gram) dengan kematian serangga uji 33,3\% (5) tidak terlihat memberikan dampak terlalu banyak terhadap mortalitas walang sangit hal tersebut dapat disebabkan karena menurunya kualitas dan virulensinya.

Pengamatan Pada 144 jam setelah aplikasi beberapa konsentrasi larutan insektisida hayati cendawan B.bassiana. pada perlakuan pertama (Tepung beras 100 gram+tepung jangkrik 15\%) dengan kematian serangga uji 6,6\% (1), perlakuan ke 2 (Tepung beras 100 gram+tepung kroto $15 \%$ ) dengan kematian serangga uji $6,6 \%$ (1) dan perlakuan ke 3 (Tepung beras 100 gram) dengan kematian serangga uji 46,6\% (7). Tepung serangga terbukti bisa menambahkan protein dalam pertumbuhan cendawan sehingga bisa meningkatkan virulensi cendawan entomopatogen b.bassiana. dengan ratarata persentase kematian Walang Sangit (gambar 1). 


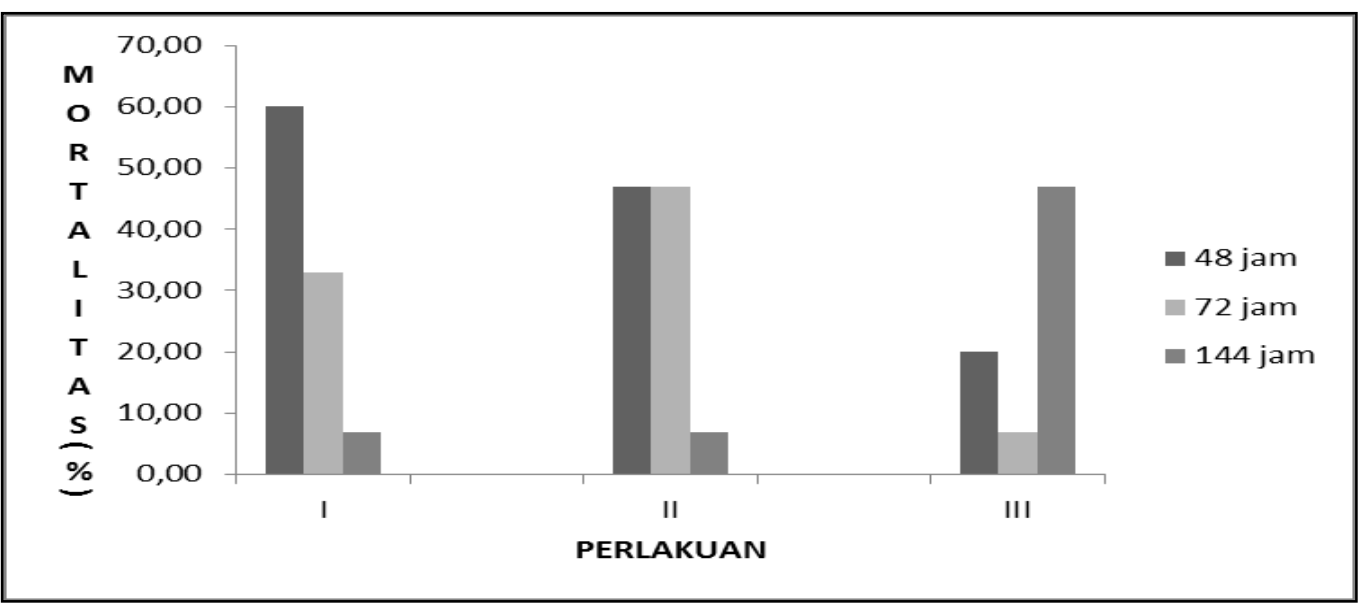

Gambar 1. Grafik mortalitas Walang Sangit setelah aplikasi bioinsektisida B.bassiana setelah 48, 72, dan 144 jam pengamatan

Selanjutnya dilakukan pengujian lebih lanjut menggunakan analisis regresi untuk melihat pengaruh jenis tepung serangga terhadap kematian Walang Sangit. Hasil pengamatan setelah 48 jam perlakuan didapatkan nilai koeefisien determinasi (R-square) adalah 0.96, hal ini berarti jenis tepung serangga memberikan pengaruh sebanyak $96 \%$ terhadap kematian walang sangit. Hasil pengamatan setelah 72 jam perlakuan didapatkan nilai koeefisien determinasi (R-square) adalah 0.42 , hal ini berarti jenis tepung serangga tidak terlalu memberikan pengaruh dikarnakan kematian hanya $42 \%$ terhadap kematian walang sangit. Hasil pengamatan setelah 144 jam perlakuan didapatkan nilai koeefisien determinasi (R-square) adalah 0.75 , hal ini berarti jenis tepung serangga memberikan pengaruh sebanyak $75 \%$ terhadap kematian walang sangit.
Menurut Nuryanti et al., (2013), penambahan media tepung serangga sangat berpengaruh terhadap virulensi cendawan B.bassiana untuk mematikan walang sangit. Walang sangit yang terinfeksi B.bassiana. menunjukkan gejala berkurangnya aktivitas gerak, selanjutnya walang sangit mulai ada tanda dibagian tubuhnya warna putih tetapi belum semuanya warna putih itu tandanya sudah mulai terinfeksi oleh cendawan B.bassiana. Beberapa waktu kemudian walang sangit mengalami kematian ditandai dengan tubuhnya yang kaku dan warna tubuhnya menjadi putih diseluruh tubuhnya diselimuti oleh cendawan B.bassiana. Untuk memastikan bahwa kematian karena terifeksi B.bassiana., maka seluruh tubuh walang sangit yang telah mati itu dipenuhi dengan warna putih akibat serangan dari cendawan B.bassiana

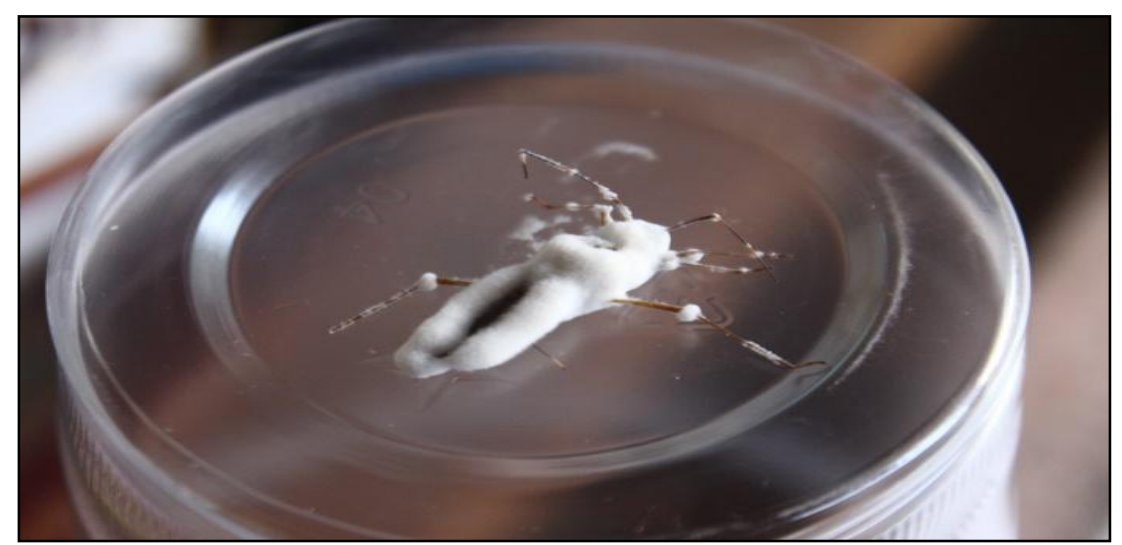

Gambar 1. Walang Sangit yang Terinfeksi B.bassiana (Dokumentasi pribadi, 2019). 
Pada awalnya pertumbuhan hifa cendawan terutama pada bagian lipatan kutikula antar ruas tubuh, selanjutnya hifa berkembang ke permukaan tubuh walang sanit dan berkembang biak di dalam tubuh walang sangit hingga dapat menyebabkan kematian pada hama walang sangit.

Mekanisme infeksi diawali dengan B.bassiana akan mengeluarkan racun yang disebut beauvericin yang menyebabkan terjadinya paralisis pada anggota tubuh serangga. Paralisis menyebabkan kehilangan koordinasi sistem gerak, sehingga gerakan serangga tidak teratur dan lama-lama kelamaan melemah, kemudian berhenti sama sekali. Setelah lebih kurang lima hari terjadi kelumpuhan total dan kematian. Toksin juga menyebabkan kerusakan jaringan, terutama pada saluran pencernaan, otot, sistem syaraf, dan system pernafasan (Tohidin \& Machdar, 1993).

\section{Lethal Time 50\%}

Pengamatan mortalitas walang sangit dilanjutkan pengamatan $\mathrm{LT}_{50}$ menggunakan probit analysis pada program microsoft excel. Hasil analisis $\mathrm{LT}_{50}$ di dapat berbagai nilai estimase atau nilai rata-rata kematian pada masing-masing perlakuan, maka dapat dilihat pada tabel 2 .

Tabel 2.Hasil uji probit analysis efektivitas insektisida hayati B.bassiana. terhadap Mortalitas pada $\mathrm{LT}_{50}$

\begin{tabular}{llll}
\hline \multicolumn{1}{c}{ No. } & \multicolumn{1}{c}{ Perlakuan (Jumlah konidia/ml) } & LT $_{50}$ (jam) \\
\hline I & TB 100 gram + TJ 15\% $\left(4,56 \times 10^{\circ}\right)$ & 48 & \\
II & TB 100 gram + TK 15\% $\left(4,4 \times 10^{\circ}\right)$ & 72 & \\
III & TB 100 gram $\left(4,24 \times 10^{\circ}\right)$ & 144 &
\end{tabular}

Ket: Perlakuan 1 (I), Perlakuan 2 (II), Perlakuan 3 (III), Tepung Beras (TB), Tepung Jangkrik (TJ), Tepung Kroto (TK).

Berdasarkan hasil uji probit analysis tabel 4.2 perlakuan I (Tepung beras 100 gram+tepung jangkrik 15\%) berada pada angka 2 yang berarti bahwa kematian 60 $\%$ walang sangit berada pada hari ke-2, dan perlakuan II (Tepung beras 100 gram+tepung kroto 15\%) berada pada angka 3 yang berarti bahwa kematian $46,6 \%$ walang sangit berada pada hari ke3, sedangkan pada perlakuan ke III (Tepung beras 100) berada pada angka 4 yang berarti bahwa kematian 46,6\% walang sangit berada pada hari ke-4. Menurut Juliani (2017), semakin kecil nilai LT maka semakin efektif suatu insektisida yang digunakan. Sehingga semakin singkat pula waktu yang dibutuhkan untuk mengendalikan walang sangit sebanyak 50\%. Pada hasil penelitian Herlinda et al., (2008), formulasi b dengan $10^{7}$ spora Metarbizium sp. per $\mathrm{ml} \mathrm{LT}_{50}$ dalam mengendalikan wereng punggung putih diperoleh pada hari ke 2,99.

\section{KESIMPULAN}

Berdasarkan penelitian uji penambahan tepung serangga pada media perbanyakan terhadap virulensi Beauveria bassiana pada walang sangit yang telah dilakukan menunjukkan hasil sebagai berikut:

1. Penambahan tepung jangkrik dan tepung kroto pada media tepung beras untuk perbanyakan cendawan B.bassiana meningkatkan mortalitas walang sangit.

2. Penambahan tepung jangkrik dan tepung kroto pada media tepung beras untuk perbanyakan cendawan B.bassiana menurunkan nilai $\mathrm{LT}_{50}$

\section{DAFTAR PUSTAKA}

BBPTP (Balai Besar Penelitian Tanaman Padi). 2015. Komulatif Luas Tambah Serangan (LTS) Organisasi Pengganggu Tanaman 
(OPT) di Instansi PPOPT

Cianjur. Arsip. Cianjur.

Herlinda S, Muhamad DU, Yulia P \&

Suwandi. 2006. Kerapatan dan

Viabilitas Spora Beauveria Bassiana

Akibat Subkultur dan Pengayaan

Media Serta Virulensinya Terhadap

Larva Plutella Xylostella (Linn.). JHPT. Tropika. 6 (2) : 70-78.

MP3C Beras Pandanwangi Cianjur. Cianjur:

Masyarakat Pelestari Padi

Pandanwangi Cianjur.

Nuryanti, N. S. P., Wibowo, L., \& Azis, A. 2013. Penambahan Beberapa Jenis Bahan Nutrisi pada Media Perbanyakan untuk Meningkatkan Virulensi Beauveria bassiana terhadap Hama Walang Sangit. Jurnal Hama dan Penyakit Tumbuhan Tropika, 12(1): 64-70.

Samsinakova, A., Misikova S \& Leopold, J. 1971. Action of Enzymatic System of Beauveria bassiana on cuticle of The Greater Way Moth Larvae (Galleria mellonella). J. Invert. Pathol. 18:322-330

Suharto, E.B., Trisusilowati, dan Purnomo, H. 1998. Kajian aspek fisiologi Beauveria bassiana dan virulensinya terhadap Helicoverpa armigera. J. Perlin. Tan. Indonesia. 4: 112-119.

Soetopo, D., dan Indriyani. 2007. Status teknologi dan prospek Beauveria bassiana untuk pengendalian serangga hama tanaman perkebunan yang ramah lingkungan. Perspektif 6(1): 29-46 http:// perkebunan litbang.go.id/publikasi/perspektif . Dakses tanggal 5 Agustus 2009.

Sembiring. S. A. 2013. Sistem Pakar Diagnosa Penyakit dan Hama Tanaman Padi. Jurnal Pelita Informatika Budi Darma (9). STMIK Budi Darma. Medan.

Susilo FX, Hasibuan R, Nordin GL \& Brown GC. 1993. The Concept of Threshold Density in Insect Pathology: $A$ Theoretical and experimental study on Tetranychus - Neozygites Mycosis.
Prosiding Makalah Simposium Patologi Serangga I. Yogyakarta, 12-13 Oktober 1993.

Tohidin, A., Lisriantu, T. dan Machdar, B.P. 1993. Daya bunuh jamur entomopatogen Beauveria bassiana (Bals.) Vuill terhadap Leptocorisa acuta di rumah kaca. Dalam Prosiding Makalah Simposium Patologi Serangga I. Yogyakarta, 12-13 Oktober 1993.

Untung K. 2001. Pengantar Pengolahan Hama Terpadu. Gadjah Mada University Press. Yogyakarta. 